\title{
NUMERICAL AND ANALYTICAL INVESTIGATION OF ALUMINIUM BRACKET STRENGTHENING
}

\author{
A. AMBROZIAK ${ }^{1}$, M. T. SOLARCZYK ${ }^{2}$, A. BIEGUS ${ }^{3}$
}

\begin{abstract}
This paper focuses on an analytical and numerical investigation of aluminium brackets used to fasten light-weight curtain walls to building facilities. The authors propose a solution to increase the load capacity of aluminium brackets by means of additional cover plates (straps). This paper also includes a short survey of literature and material properties concerning the EN AW-6060 T6 aluminium alloy. This paper suggests an initiation of a comprehensive investigation on aluminium brackets.
\end{abstract}

Keywords: aluminium bracket, cover plates, mechanical properties, EN AW-6060 T66, FEM

\section{INTRODUCTION}

Aluminium alloys are commonly used in the aircraft industry, building and construction industry, electricity, packaging, transportation, etc. These alloys exhibit intermediate strength and sufficient ductility. The main alloying elements are copper, magnesium, zinc, silicon, manganese, and lithium. The investigated aluminium bracket is made of aluminium alloy EN AW-6060/EN AW-Al MgSi (according to standard [27]) in temper T66 (according to standard [26]). The civil engineering application of the EN AW-6060 T66 concerns construction and execution of light-weight suspended or filling-type curtain walls, roofs, skylights, and other three-dimensional structures. Structural design is intended to prohibit progressive collapse of surrounding elements or an entire construction in the

\footnotetext{
${ }^{1}$ DSc., PhD., Eng., Prof. GUT, Gdansk University of Technology, Faculty of Civil and Environmental Engineering, St. Gabriela Narutowicza 11/12, 80-233 Gdansk, Poland, e-mail: ambrozan@pg.gda.pl

${ }^{2}$ MSc., Eng., Gdansk University of Technology, Faculty of Civil and Environmental Engineering, St. Gabriela Narutowicza 11/12,80-233 Gdańsk, Poland, e-mail: maciej.solarczyk@pg.gda.pl

${ }^{3}$ Prof., DSc., PhD., Eng., Wroclaw University of Science and Technology, Faculty of Civil Engineering, St. Wybrzeże Wyspiańskiego 27, 50-370 Wrocław, Poland, e-mail: antoni.biegus@pwr.edu.pl
} 
case of single component failure. An application example below illustrates a mullion-transom wall system (see Fig. 1). The load-bearing structure of this system consists of vertical (mullions) and horizontal (transoms) aluminium profiles of a box section connected to the structure by aluminium brackets.

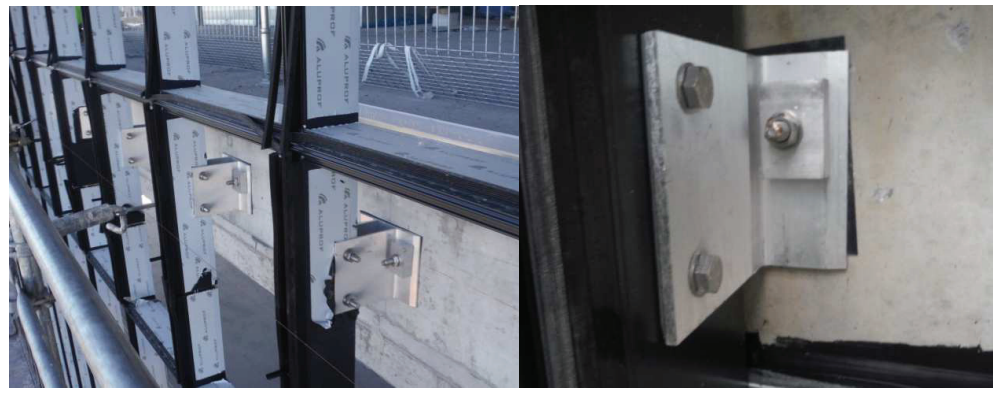

Fig. 1. Mullion-transom wall system - aluminium profiles and brackets

Aluminium bracket design is a complex process; a high probability exists that it can be conducted improperly. Preliminary research on the investigated aluminium brackets (see Fig. 2) reveals that both the load-bearing capacity and the stiffness are insufficient for carrying the anticipated design loads. The replacement of old, existing brackets with new ones triggers high material losses and delays in the building construction process. Bracket strengthening is implemented by the presence of cover plates (straps). Quick decision-making is the reason why the geometric parameters adopted on the basis of the recommendations of literature bring about coarse strength estimation. This paper provides theoretical and numerical analysis in order to assess the behaviour of loaded aluminium brackets with and without additional cover plates (straps). The FEM (finite element method) solution is directed at the safe performance of the aluminium bracket and its mechanical response. This study is intended to properly recognize the behaviour of the proposed aluminium bracket strengthening. 

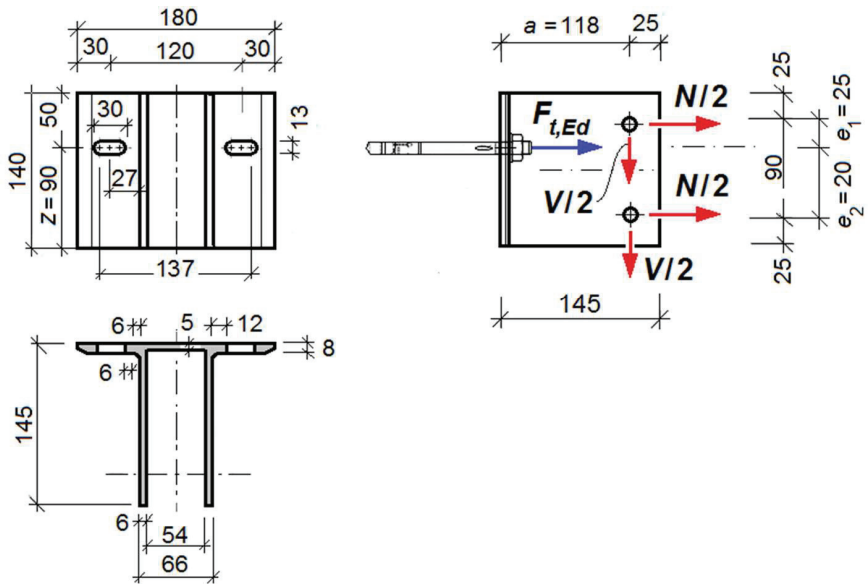

Fig. 2. Investigated aluminium bracket

\section{MATERIAL PROPERTIES OF EN AW-6060 T66}

Firstly, a short paper survey presents the mechanical properties of the EN AW-6060 T66 aluminium alloy. De Kanter [8] investigated the crush behaviour of monolithic aluminium cylinders and externally fibre-reinforced aluminium cylinders. Additionally, material parameters of aluminium alloy 6060-T66 were presented due to tensile tests. Maljaars et al. [17] presented creep experiments on 6060-T66 and 5083-H111 alloys at high temperatures by means of a traditional Dorn and Harmathy model. Maljaars et al. [18]; [19] performed a series of tests on 6060-T66 and 5083-H111 aluminium alloy compression members to assess their local buckling behaviour at high temperatures. Zheng and Zhang [32] proposed practical critical temperature formulas of 6060-T66 and 5083-H112 aluminium alloy I-beams and developed finite element models to simulate their fire-triggered flexural and flexural-torsional buckling behaviours. Käfer et al. [14] performed axial compression tests on EN AW 6060-T66 aluminium circular tubes. Mróz [23] investigated the C-channel cross-section beams/columns made of 6060 T4, T5, T6, and T66 aluminium alloys under compressive axial impact. One of the domains of a widely known Perzyna viscoplastic model is the mechanical behaviour of aluminium alloys. Szymczak and Kujawa [29] investigated the local stability of thin-walled compressed flanges of aluminium alloy channel columns and beams. Mróz and Mania [22] focused on dynamic stability analysis of EN AW 6060-T66 pre-aged aluminium profiles subjected to dynamic impulse loading. 
Material description due to a variety of loads and selection of relevant constitutive models is an essential issue to be completed prior to the performance of other stages due to a variety of loads and selection of relevant constitutive models. In 1943 Ramberg and Osgood [28] proposed an elastoplastic model related to aluminium alloy, stainless steel, and carbon steel. The stress-strain $(\sigma-\varepsilon)$ curves corresponding to the Ramberg-Osgood material law are:

$$
\varepsilon=\frac{\sigma}{E}+0.002\left(\frac{\sigma}{f_{0.2}}\right)^{n}
$$

Where: $E, f_{0.2}$, and $n$ are tensile modulus, $0.2 \%$ proof strength, and dimensionless Ramberg-Osgood parameter, respectively.

Maljaars et al. [19] conducted a laboratory test to specify the following parameters of the EN AW-6060 T66 aluminium alloy: $E=69000\left[\mathrm{~N} / \mathrm{mm}^{2}\right], f_{0.2}=205\left[\mathrm{~N} / \mathrm{mm}^{2}\right], n=22[-]$.

The Ramberg-Osgood relationship is widely applied in engineering practices. On the other hand, different approaches exist for constitutive modelling of aluminium alloys (e.g. nonlinear elastic, viscoplastic, viscoelastic models). References [3] and [16] present the elasto-viscoplastic BodnerPartom model (see e.g. [2], [6]) reflecting the aluminium alloy performance.

The stress-strain curves based on the tensile tests for the EN AW-6060 T66 aluminium alloy presented by Mróz and Mania [22] and Maljaars et al. [18] are compared in Fig. 3. The presented tensile tests results converge in the strain range $\varepsilon \in(0 \div 0.005)$. Table 1 includes material properties of 6060 T66 aluminium alloy based on literature data. The material properties are highly dispersed, e.g. De Kanter [8] specifies that minimum yield stress equals $185 \mathrm{MPa}$ while Mróz and Mania [22] assess its value as 206.2. The dispersion arises from the various dimensions of the test specimens, the speed of loading, or specimen directions in extrusion (longitudinal, transverse).

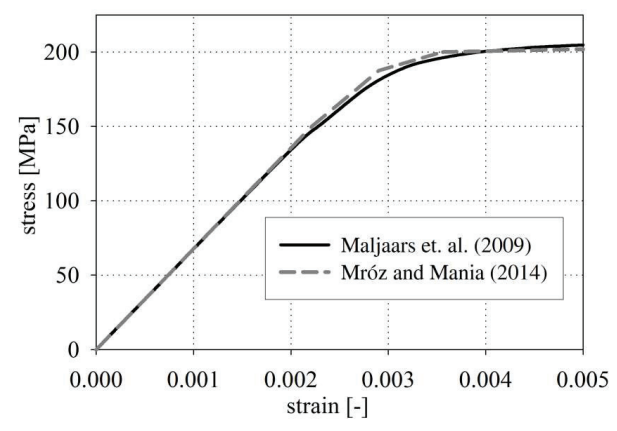

Fig. 3. Experimental material characteristics 
On the other hand, engineering standards specify mechanical properties of materials to be strictly followed in structural analysis. Material parameters for the EN AW-6060 T66 aluminium alloy are included in standard [11] (see Table 2). The properties are divided into two groups due to the wall thickness of the aluminium alloy elements. The standard gives safety values of mechanical properties which should be taken into account in engineering calculation of aluminium structures, e.g. according to standard [10].

Table 1. Material data for $6060 \mathrm{~T} 66$ at room temperature

\begin{tabular}{|c|c|c|c|c|c|}
\hline properties & $\begin{array}{l}\text { De Kanter [8] } \\
\text { 2) }\end{array}$ & $\begin{array}{ll}\text { De } & \text { Kanter } \\
{[8]} & \end{array}$ & $\begin{array}{l}\text { Käfer et al. } \\
{[14]}\end{array}$ & $\begin{array}{l}\text { Maljaars et al. } \\
\text { [18] }\end{array}$ & $\begin{array}{l}\text { Mróz and } \\
\text { Mania [22] }\end{array}$ \\
\hline Tensile modulus [MPa] & 69000 & 69000 & 69000 & 69000 & 63990 \\
\hline Tangent modulus [MPa] & ns & ns & 320 & ns & ns \\
\hline Poisson's ratio [-] & 0.3 & 0.3 & 0.3 & ns & 0.331 \\
\hline Density $\left[\mathrm{kg} / \mathrm{m}^{3}\right]$ & ns & ns & 2800 & ns & ns \\
\hline Yield stress [MPa] & $185^{1)}$ & $197^{1)}$ & 206 & $205^{1)}$ & 206.2 \\
\hline Ultimate stress [MPa] & 206 & 215.2 & ns & ns & 229.9 \\
\hline Ultimate strain [-] & 0.129 & 0.134 & ns & ns & ns \\
\hline \multicolumn{6}{|c|}{$\begin{array}{l}\text { ns - not specified } \\
\text { 1) value of } 0.2 \% \text { proof strength }\end{array}$} \\
\hline
\end{tabular}

Table 2. Mechanical properties of extruded profiles (EN AW-6060 T66) according to EN 755-2 [11]

\begin{tabular}{|l|l|l|}
\hline properties & $\begin{array}{l}\text { Wall thickness } \\
\mathrm{e} \leq 3[\mathrm{~mm}]\end{array}$ & $\begin{array}{l}\text { Wall thickness } \\
3<\mathrm{e} \leq 25[\mathrm{~mm}]\end{array}$ \\
\hline $\begin{array}{l}\text { Proof stress } \mathrm{R}_{\mathrm{e} 0.2} \\
\text { min [MPa] }\end{array}$ & 160 & 150 \\
\hline $\begin{array}{l}\text { Tensile strength } \mathrm{R}_{\mathrm{m}} \\
\text { min [MPa] }\end{array}$ & 215 & 195 \\
\hline Elongation min & 6 & 8 \\
\hline Elongation max & 6 & 8 \\
\hline Brinell hardness in Ramberg-Osgood & 70 & 65 \\
\hline $\begin{array}{l}n \text {-value in } \\
\text { expression for plastic analysis }\end{array}$ & 16 & 18 \\
\hline
\end{tabular}

It can be seen that the EN AW-6060 T66 aluminium alloys are still being tested and developed. 


\section{ANALYTICAL INVESTIGATION}

The concept of an aluminium bracket end plate strengthened by additional cover plates (straps) (see Figs. 2 and 4) can be compared with the concept of the reinforced T-stub flange with backing plate stiffeners. The bolted end plate beam-to-column connections are widely applied in steel and aluminium structures. In 1974 Zoetemeijer [33] developed a design method directed at the tension zones of statically loaded bolted beam-to-column connections assuming the plastic behaviours of the flanges and the bolts. The study by Nair et al. [24] focused on tension and the prying force effect to find out that the load-carrying capacity of bolted connections can be substantially reduced by the prying action. Moore and Sims [21] presented tests on tension region models of T-stub connections and on full connections augmented with backing plate stiffeners. Moore and Gibbons [20] presented a step-by-step design procedure for flush and extended end plate connections with backing plate stiffeners. Grogan and Surtees [12] developed a new method to assess local column flange reinforcement in end plate connections, incorporating rolled steel angle sections. Cases of bolted Tstubs strengthened by backing plate stiffeners were studied in [1]. The authors analysed the T-stub behaviour on the basis of global load-displacement curves, evolution of the bolt load, and contact pressure due to the prying force effect. Lastly, Katula and Dunai [15] provided an experimental background to develop a design model development, studying the load-bearing capacity of joints, bolt force distribution, and end plate deformations. Due to the component method included in the standards, the bolted beam-to-column connection is deconstructed into its elementary components; the most important is the equivalent T-stub in the tension zone. The principles of the component method are based on Zoetemeijer's work [33].

The investigated aluminium bracket (see Fig. 2) consists of an end plate of variable thickness ( $8 \mathrm{~mm}$ and $5 \mathrm{~mm}$ in the middle) and two $6 \mathrm{~mm}$ thick cantilever plates. The problem concerns an end plate $180 \mathrm{~mm}$ wide and $140 \mathrm{~mm}$ high with two cantilever plates $145 \mathrm{~mm}$ wide and $140 \mathrm{~mm}$ high. The cover plates are $40 \mathrm{~mm}$ wide, $60 \mathrm{~mm}$ high, and $20 \mathrm{~mm}$ thick (straps, see Fig. 4) and are designed to increase the load capacity of an aluminium bracket. The aluminium bracket is made of EN AW-6060 T66 aluminium alloy. Table 2 includes mechanical properties in the case when thickness is lower than $3 \mathrm{~mm}$. Two oval holes $(13 \mathrm{~mm} \times 30 \mathrm{~mm})$ in the end plate are provided to fasten the aluminium bracket to the building structure by means of two bolt anchors (M12 - diameter $d=12 \mathrm{~mm}$ ) made of stainless steel, see Fig. 1. 


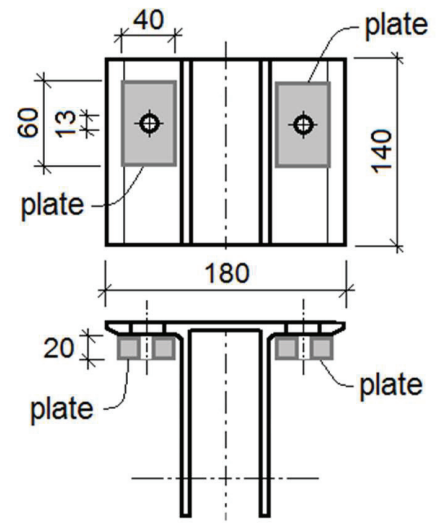

Fig. 4. Analysed aluminium bracket with cover plates (straps)

Both the geometry and construction of the aluminium bracket made it impossible to computationally assess the resistance and stiffness (the so-called component method, including yield line analysis) given in [10] and [9]. On the other hand, the thickness of the end plate according to standard [25] can be computed by the formula:

$$
t \geq t_{\min }=1.2 \sqrt{\frac{c S_{t, R}}{b_{s} f_{d}}}
$$

where: $c$ is the distance between the edge of the hole and the weld or the edge of the fillets (breaking arm of the bolt, where: $c \leq d$ ); $S_{t, R}$ is design tensile resistance of a bolt mounted in the end plate (while it is not fully loaded the value $S_{t, \text { Ed }}$ the force in the most loaded bolt is assumed); ${ }^{b}$ is the effective width of a single bolt; $f_{d}$ is the design yield strength of the end plate.

It should be noted that additional requirements are taken into account:

$$
b_{s} \leq 2(c+d)
$$

where: $d$ is the diameter of the bolt mounted in the end plate.

The design yield strength $f_{d}$ of the EN AW-6060 T66 aluminium alloy is specified as (see [10]): 


$$
f_{d}=\frac{f_{o}}{\gamma_{M 1}}=\frac{150}{1.10}=136.36 \mathrm{MPa}
$$

where: $f_{o}$ is yield strength and $\gamma_{M 1}$ is the partial factor for resistance.

It should be noted that formula (3.1) refers to the evaluation of the minimum thickness of the end plate with round holes (normal) and in the so-called simple connection (screw connection transferring end shear force only due to its negligible resistance to rotation, and therefore not transmitting significant moments). Oval holes in the end plate of the bracket are designed, and this results in a significant resistance reduction of the bracket (relative to the bracket with round holes) and deformation increase. Additionally, the safety factor is decreased both in tension and bending of the bracket, as follows:

$$
M_{E d}=V \cdot a+\frac{N}{2} \cdot e_{1}-\frac{N}{2} \cdot e_{2}
$$

where: $V, N$, and $a, e_{1}, e_{2}$ are the vertical force, horizontal force, and the force arms (see Fig. 2), respectively.

The presented joint is complex, contrary to the assumptions taken in formula (3.1). Concluding, the computation of the minimum thickness of the end plate by formula (3.1) in the case of the analysed bracket is incorrect.

The strength and deformation of the T-stub connection and the minimum thickness of the end plate $t_{\min }$ are affected by the breaking arm $c$ of the bolt. Its high value reduces the safety factor and increases deformation of the bracket, while the prying effect increases the force in the bolts. It is therefore recommended to embed the bolts as close as possible to the tensile edge of the cantilever plate of a bracket. The design of the butt joints should consider condition $c \leq d$.

In the case of the examined aluminium bracket, the extreme variant of the oval holes yields the formula for $c$ :

$$
c_{\max }=27-6+2=23 \mathrm{~mm}
$$

The T-stub connections with thin end plates (when ${ }^{t<t_{\min }}$ ) are semi-rigid (flexible and deformable) and of a relatively low capacity. The resistance increase of the connections is achieved 
by means of thick end plates $\left(t \geq 1.67 t_{\min }\right)$. Hence, the prying effect does not occur and the connection remains rigid.

In order to increase the resistance and stiffness of the bracket cover plates (straps), the end plates should be strengthened. They are located under the washers of the bolts. They trigger a reduction of arm $c$ and increase the flexural stiffness of the end plate.

In accordance with the order in [7], in the case of cover plates (straps) of minimum thickness $t_{p}=1.5 d$ the T-stub connection can be considered rigid, so a resistance and stiffness check of the end plate is not required. While appropriately designed cover plates (straps) are applied, the breaking arm of the bolt is less than $5 \mathrm{~mm}$. The following dimensions of cover plates (straps) are proposed: width $40 \mathrm{~mm}$, height $60 \mathrm{~mm}$, and thickness $20 \mathrm{~mm}$ (see Fig. 4).

In order to assess bracket resistance the following design load values are taken: horizontal force $N=16.54 \mathrm{kN}$ and vertical force $V=6.05 \mathrm{kN}$ (see [5]). The tensile load in the bolt $F_{t, E d}$ (see Fig. 2) can be computed by means of an equilibrium equation, as follows:

$$
\begin{aligned}
& F_{t, E d}=S_{t, \mathrm{Ed}}=0.5\left(N+\frac{V \cdot a+N / 2 \cdot e_{1}-N / 2 \cdot e_{2}}{z}\right)= \\
& =0.5\left(16.54+\frac{6.05 \cdot 0.12+16.54 / 2 \cdot 0.025-16.54 / 2 \cdot 0.065}{0.09}\right)=10.47 \mathrm{kN}
\end{aligned}
$$

It should be pointed out that the permissible tensile load for a single bolt anchor (e.g. FAZ II 12 A4) in concrete $\mathrm{C} 20 / 25$ for the combination of tensile loads, shear loads, and bending moments is equal to $11.9 \mathrm{kN}$ (see e.g. Fisher web site [13]). This value should be higher than the one specified in Eq. (3.6) to assume safe load transfer to a building structure. It should be noted that introducing higher concrete strength classes make it possible to achieve higher permissible loads.

The effective width of the end plate is

$$
b_{s} \leq 2 \cdot(c+d)=2 \cdot(5+12)=34 \mathrm{~mm}
$$

The effective width $b_{s, \text { red }}$ should be reduced due to yield stress occurrence in the end plate at the holeweakened section: 


$$
b_{s, \text { red }}=34-13=21 \mathrm{~mm}
$$

The requirements may be derived for minimum thickness of the end plate according to Eq. (3.1) while applying cover plates (straps, see Fig. 4) as:

$$
t_{\min }=1.2 \sqrt{\frac{5 \cdot 10.47 \cdot 10^{-3}}{21 \cdot 136.36}}=5.1 \mathrm{~mm}<8 \mathrm{~mm}
$$

The required minimum thickness is less than $8 \mathrm{~mm}$ (thickness of the end plate under cover plates, see Fig. 2). The cover plates (see Fig. 4) meet the requirements, concerning increment of the load capacity of the aluminium bracket.

\section{APPLICATION TO FINITE ELEMENT ANALYSIS}

In order to verify the analytical procedure results, numerical simulations of the aluminium bracket behaviour are performed. Two solid models shown in Fig. 5 with and without cover plates (straps) are considered in the finite element analysis. The solid models assume four-node isoparametric three-dimensional tetrahedron elements (Element 134, see User Documentation Marc [30]). The aluminium bracket is modelled by a mesh exceeding 260000 solid elements. All numerical simulations are carried out by means of an implicit FEM package MSC.Marc. The following deformable body contact types are specified in model_1 (see Fig. 5): plate, bracket, washer1, washer2, bolt1, bolt2, and model_2 incorporates two additional cover plates (straps): stemp1, stemp2. The bracket is fastened to a $30 \mathrm{~mm}$ thick S355 steel plate (plate, see Fig. 5) by two A4-80 stainless steel bolts (bolt1 and bolt2, see Fig. 5). External edges of the steel plate are supported (the translations Ux, Uy, and Uz are fixed). Washers under screw cups are also included in the model. A segment-tosegment method with a touching contact type and friction governed by the bilinear Coulomb model is applied to simulate contact conditions between specified deformable body contacts (see e.g. [4]). 


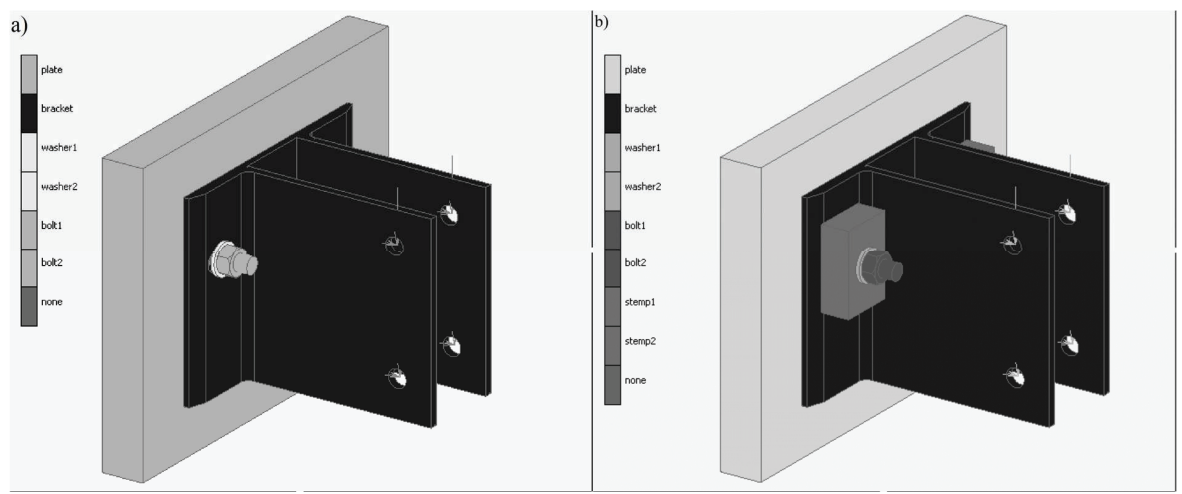

Fig. 5. FEM solid model - a) model_1, b) model_2

The material of the bracket, bolts, and the plate is assumed as plastic throughout the analysis. The input mechanical properties of the material applied in FE analysis are given in Table 3. The bolts withstand the $20 \mathrm{MPa}$ initial prestressing state. The friction coefficient between steel and the aluminium alloy is assumed to be 0.4 (see e.g. Więckowski and Adamus [31]). A horizontal force of $\mathrm{N} / 4=4.135 \mathrm{kN}$ and a vertical force of $\mathrm{V} / 4=1.5125 \mathrm{kN}$ are applied at four points of the cantilever plates. The bolts are connected at these points with the mullions by means of an aluminium bracket; see Fig. 1. In the FE model, each point is connected with cantilever plates by 40 truss elements, transferring the load to the bracket.

Table 3. FEM analysis - material properties

\begin{tabular}{|l|l|l|l|}
\hline properties & EN AW-6060 T66 & $\begin{array}{l}\text { A4-80 stainless } \\
\text { steel }\end{array}$ & S355 steel \\
\hline Tensile modulus [MPa] & 70000 & 200000 & 210000 \\
\hline Poisson's ratio [-] & 0.3 & 0.3 & 0.3 \\
\hline Density $\left[\mathrm{kg} / \mathrm{m}^{3}\right]$ & 2700 & 8000 & 7800 \\
\hline Yield strength $[\mathrm{MPa}]$ & 150 & 600 & 355 \\
\hline
\end{tabular}

The maps of displacements Uz, total displacements, and equivalent von Mises (Huber-MisesHencky, HMH) stresses are shown in Figs. 6, 7, and 8 for model_1 and in Figs. 9, 10, and 11 for model_2. Table 4 displays the maximum values of displacement $\mathrm{Uz}$, total displacement, and HMH stress in the end plate. The introduction of cover plates decreases the maximum Uz and the total displacement in a 40-50\% range. Maximum HMH stresses in the end plate reach $96 \mathrm{MPa}$ in model_2, while model_1 (without straps) sets the plastic range to $150 \mathrm{MPa}$. The contact statuses for model_1 and model_2 are presented in Fig. 12 and Fig. 13, respectively. It should be noted that contact status 
is set to a value of 1.0 as soon as contact is detected. While full horizontal and vertical loads are applied, the back part of the end plate is in contact with the foundation on partial lateral areas only. On the face part of the end plate, the washers (Fig. 12) and straps (Fig. 13) are impressed. Fig. 14 displays a graphical visualisation of the $\mathrm{Uz}$ and total displacements in the end plate in the upper middle part of the aluminium bracket. The displacement increment is variable throughout the analysed models. The application of the cover plates (straps) in model 2 is decisive while strengthening the end plate.

Table 4. Results of FEM analysis

\begin{tabular}{|l|l|l|l|}
\hline properties & model_1 & model_2 & (model_2/model_1) \\
\hline $\max$ Uz [mm] & 1.044 & 0.608 & $58 \%$ \\
\hline $\begin{array}{l}\text { max Total } \\
\text { Displacement [mm] }\end{array}$ & 1.649 & 0.778 & $47 \%$ \\
\hline $\begin{array}{l}\text { HMH stress [MPa] in } \\
\text { base plate }\end{array}$ & $\begin{array}{l}150 \\
\text { (plastics regions) }\end{array}$ & 96 & $64 \%$ \\
\hline
\end{tabular}

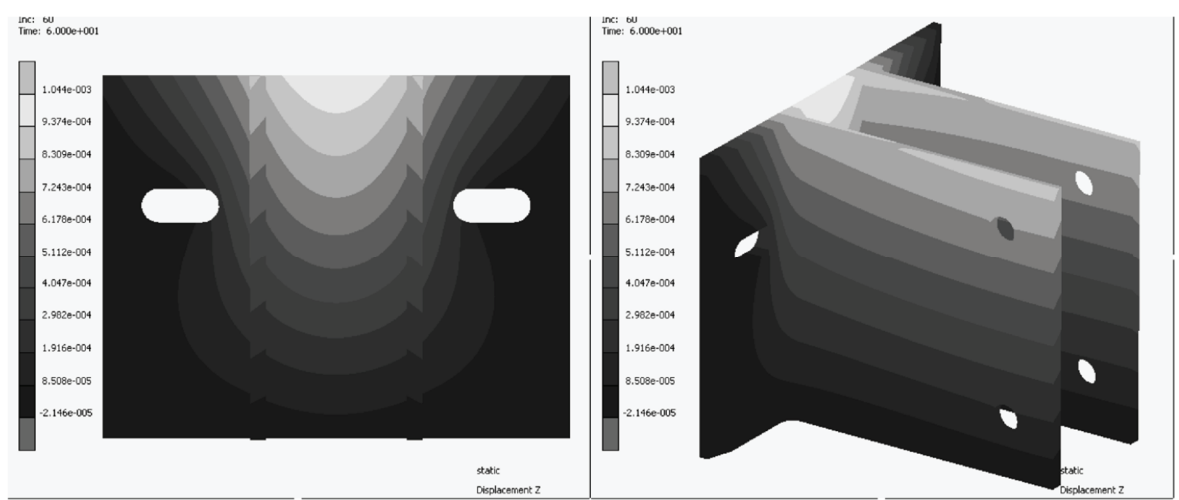

Fig. 6. Displacement Uz-model_1 


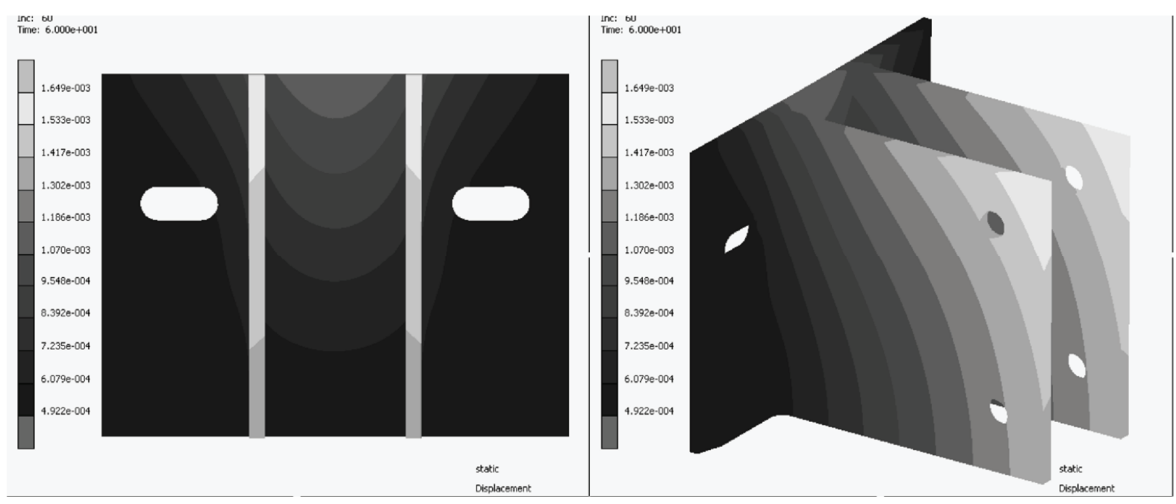

Fig. 7. Total displacement - model_1

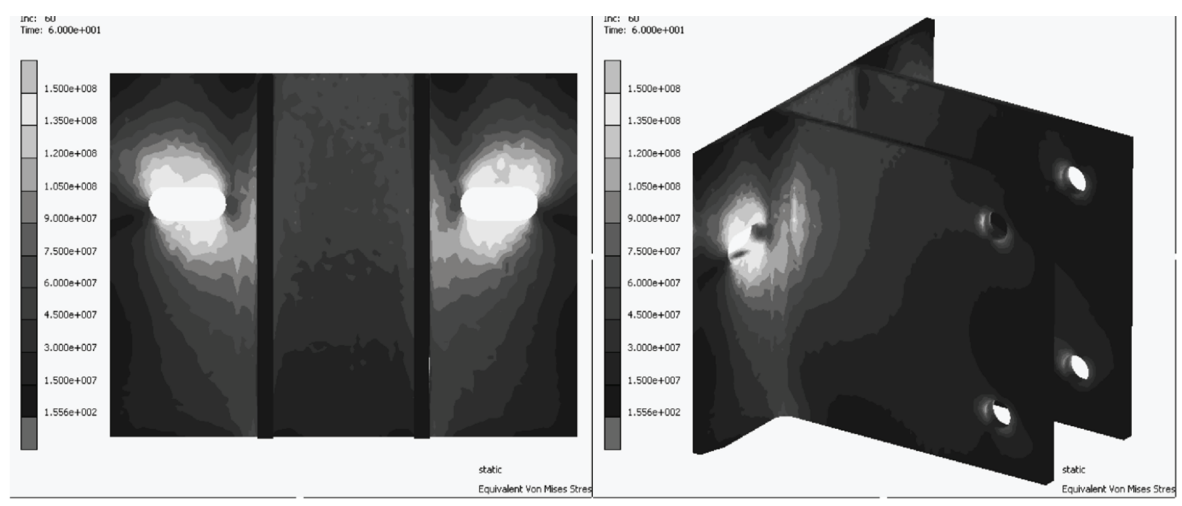

Fig. 8. Equivalent von Mises stress - model_1

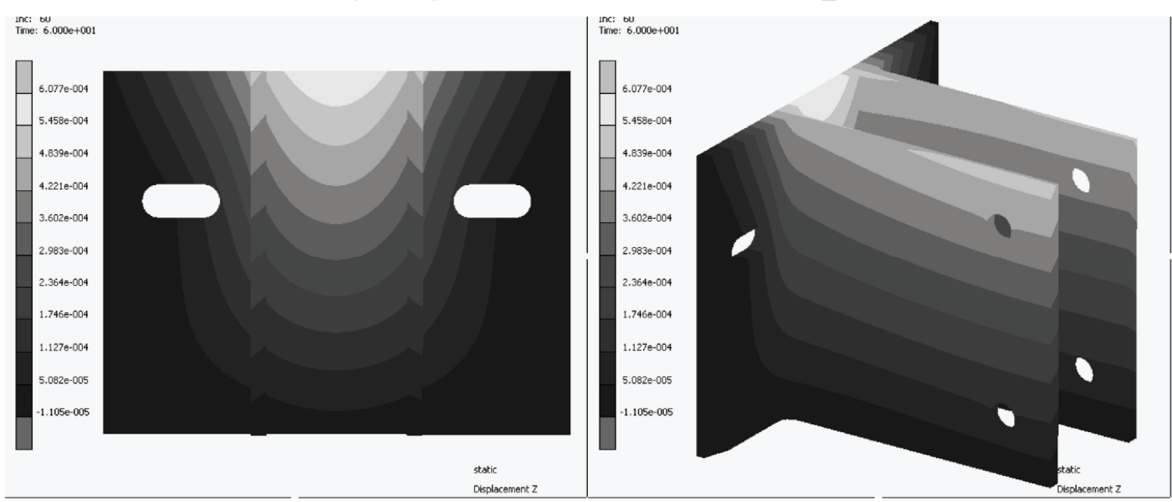

Fig. 9. Displacement Uz - model_2 


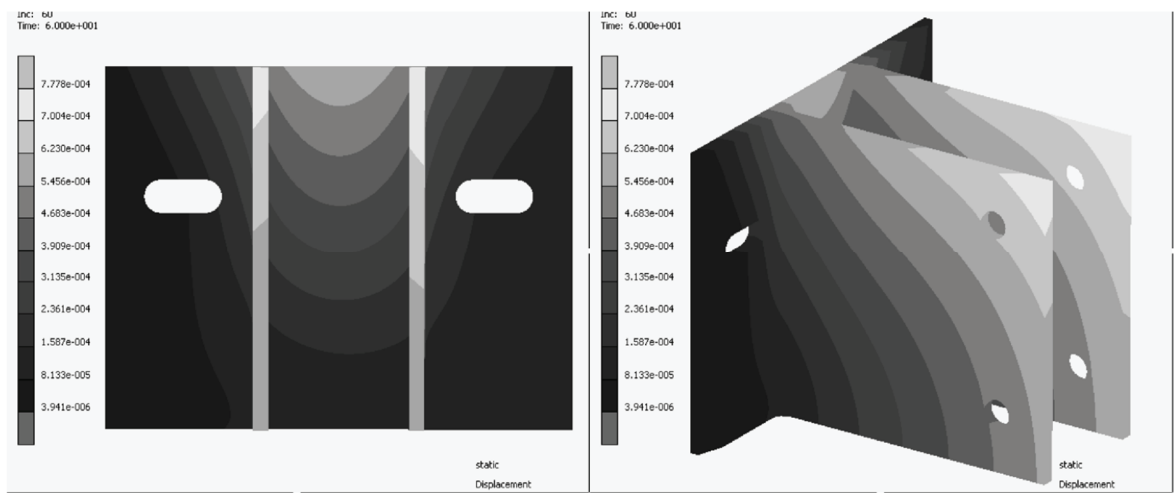

Fig. 10. Total displacement - model_2

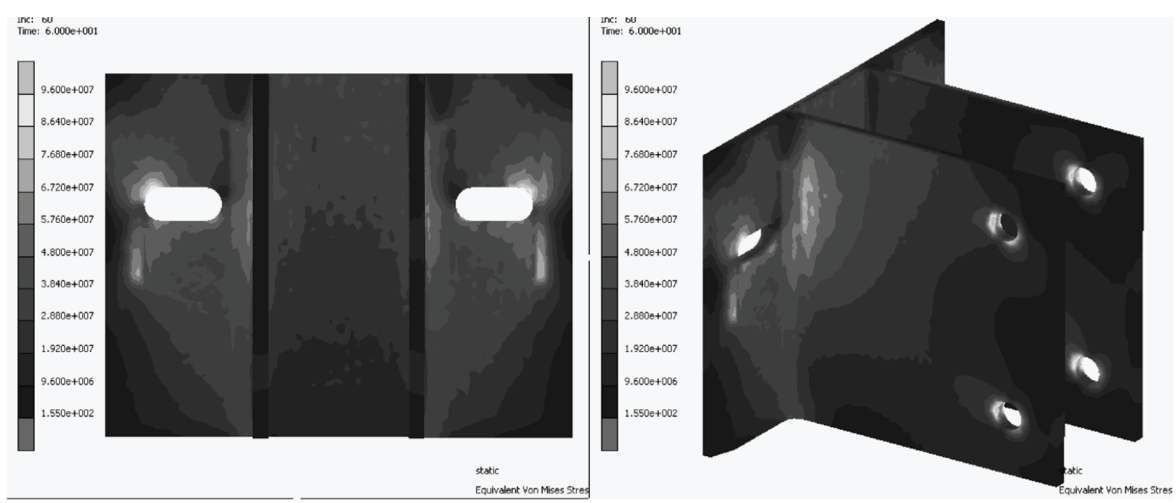

Fig. 11. Equivalent von Mises stress - model_2

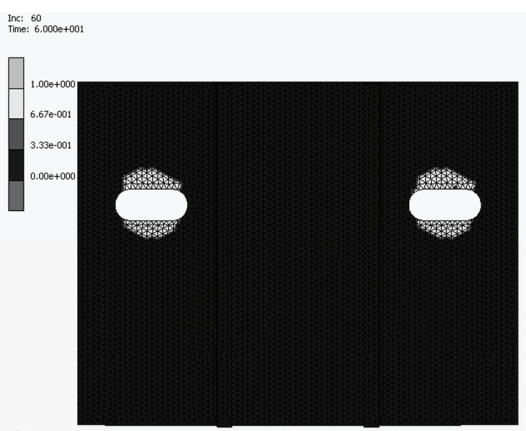

a)

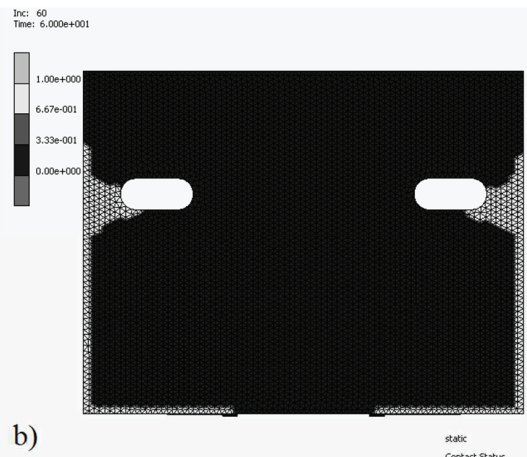

Fig. 12. Contact status - model_1: a) front view, b) rear view 

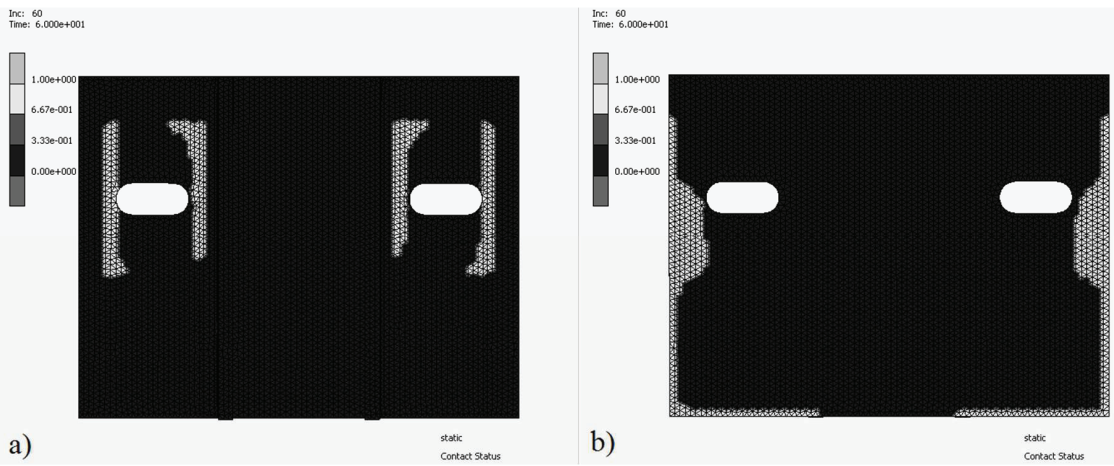

Fig. 13. Contact status - model_2: a) front view, b) rear view

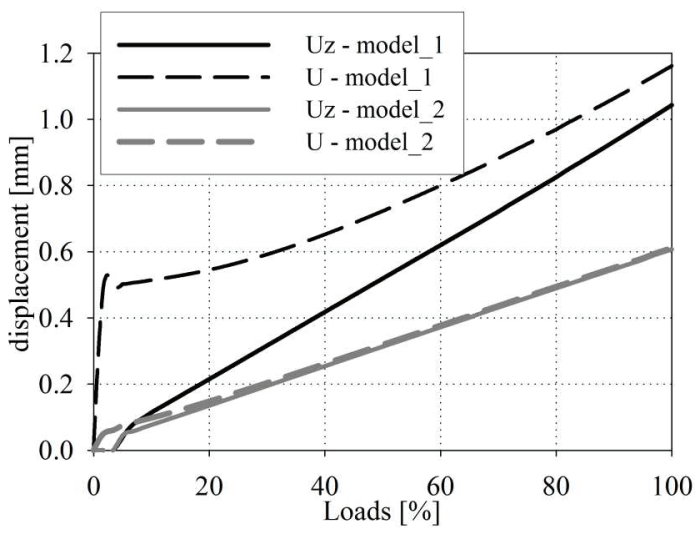

Fig. 14. Uz and total displacements in end plate

\section{CONCLUSIONS}

The authors investigated theoretically and numerically the response of an aluminium bracket with additional straps to an operational load. It can be concluded that the introduction of additional cover plates (straps, see Fig. 4) results in a 50\% increase in the load-carrying capacity of the aluminium bracket. The investigation is aimed at the reflection improvement of aluminium bracket behaviour. A possible application of the proposed results is a class of problems inherent to aluminium bracket assembly.

Building site supervision makes it possible to recognize new technologies and applications of new ideas. The first author's professional duty is as a construction site supervisor on the Alchemia 
building site in Gdansk (Poland) which displays aluminium brackets to connect the structure to the mullion-transom wall system. This investigation confirms that the quality of the aluminium brackets, equipment, and systems is sufficiently high. The obtained results provide a motivation for the authors to continue the outlined research, incorporating extended experimental investigations.

\section{REFERENCES}

1. Z. Al-Khatab, A. Bouchaïr, “Analysis of a bolted T-stub strengthened by backing-plates with regard to Eurocode 3”, Journal of Constructional Steel Research, 63: 1603-1615, 2007.

2. A. Ambroziak, "Application of elasto-viscoplastic Bodner-Partom constitutive equations in finite element analysis", Computer Assisted Mechanics and Engineering Sciences, 55(3): 405-429, 2007.

3. A. Ambroziak, P. Kłosowski, Ł. Pyrzowski, "Elasto-viscoplastic properties of AA2017 aluminium alloy", Task Quarterly, 15(1): 5-20, 2011.

4. A. Ambroziak, P. Kłosowski, "MSC.Marc/Mentat. Example of calculations (in Polish)", Gdansk University of Technology Publishing House, Gdansk 2017.

5. A. Biegus, W. Seidel, "Experts opinion on strengthening of aluminium brackets" (in Polish), 1-9, 2016.

6. S. R. Bodner, Y. Partom, "Constitutive equations for elastic-viscoplastic strain-hardening materials", Journal of Applied Mechanics, 42: 385-389, 1975.

7. DASt-Ri 010, Anwendung hochfester Schrauben im Stahlbau. Deutcher Ausschuss für Stahlbau, Juni 1976.

8. J. L. C. G. De Kanter, "Energy absorption of monolithic and fibre reinforcement aluminium cylinders" $\mathrm{PhD}$ thesis, Delft University of Technology, Netherlands, 2006.

9. EN 1993-1-8 Eurocode 3 - Design of steel structures - Part 1-8: Design of joints, 2012.

10. EN 1999-1-1 Eurocode 9 - Design of aluminium structures - Part 1-1: General structures rules, 2011.

11. EN 755-2, Aluminium and aluminium alloys. Extruded rod/bar, tube and profiles. Mechanical properties, 2016.

12. W. Grogan, J. O. Surtees, "Experimental behaviour of end plate connections reinforced with bolted banking angles", Journal of Constructional Steel Research, 50: 71-96, 1999.

13. Fisher web site www.fischer.co.uk/PortalData/1/Resources/service/salesdocuments/documents/FAZ_II Prospekt en 505099-3-mitKlapper.pdf

14. B. Käfer, V. K. Bheemineni, H. Lammer, M. Kotnik, F. O. Riemelmoser, "Effects of position and cut-out length on the axial crushing behaviour of aluminium tubes: Experimental and simulation", International Journal of Mechanical, Aerospace, Industrial, Mechatronic and Manufacturing Engineering, 7(11): 2157-2164, 2013.

15. L. Katula, L. Dunai, "Experimental study on standard and innovative bolted end-plate beam-to-beam joints under bending", Steel and Composite Structures, 18(6): 1423-1450, 2015.

16. P. Kłosowski, A. Mleczek, "Identification of Bodner-Partom viscoplastic model parameters for some aluminium alloys at elevated temperature", Journal of Materials in Civil Engineering, doi: 10.1061/(ASCE)MT.19435533.0001875, 2017.

17. J. Maljaars, F. Soetens, L. Katgerman, "Constitutive model for aluminum alloys exposed to fire conditions", Metallurgical and Materials Transactions A, 39A: 778-789, 2008.

18. J. Maljaars, F. Soetens, H. H. Snijder, "Local buckling of aluminium structures exposed to fire. Part 1: tests", Thin-Walled Structures, 47: 1404-1417, 2009.

19. J. Maljaars, L. Twilt, F. Soetnes, "Flexural buckling of fire exposed aluminium columns", Fire Safety Journal, 44: 711-717, 2009.

20. D. B. Moore, C. Gibbons, "The design of flush and extended end-plate connections with backing plates", in Construction Steel Design: World developments, Edited by P. J. Dowling, J. E. Harding, R. Bjorhovde, E. Martinez-Romero, Elsevier Science Publisher LTD, England, 225-239, 1992.

21. D. B. Moore, P. A. C. Sims, "Preliminary investigation into the behaviour of extended end-plate steel connections with backing plates", Journal of Constructional Steel Research, 6(2): 95-122, 1986.

22. A. Mróz, R. J. Mania, "The complex influence of aluminium aging on the dynamic response of the thin-walled AL-6060 alloy profile", Thin-Walled Structures, 79: 147-153, 2014

23. A. Mróz, "The viscoplastic effect in the heat-treated, thin-walled AL-6060 alloy profiles subjected to compressive axial impact”, Mechanics and Mechanical Engineering, 18(1): 53-71, 2014. 
24. R. S. Nair, P. C. Birkemoe, W. H. Munse, "High Strength Bolts Subject to Tension and Prying", Journal of the Structural Division, ASCE, 100(2): 351-372, 1974.

25. PN-90/B-03200. Steel structures - Structural analysis and design (in Polish), 1990.

26. PN-EN 515. Aluminium and aluminium alloys. Wrought products. Temper designations, 1996.

27. PN-EN 573-3:2014. Aluminium and aluminium alloys. Chemical composition and form of wrought products. Chemical composition and form of product, 2014.

28. W. Ramberg, W. R. Osgood, "Description of stress-strain curves by three parameters”, NACA Technical Note No. 902, 1943.

29. Cz. K. Szymczak, M. Kujawa, "Local buckling of thin-walled channel member flange made of aluminum alloy", AIP Conference Proceedings, 1822, 020014; doi: 10.1063/1.4977688, 2017.

30. User Documentation, Marc ${ }^{\circledR} \quad(2016)$ Volume B: Element Library, https://simcompanion.mscsoftware.com/infocenter/index?page=content\&id=DOC11102\&cat=MARC_DOCU MENTATION_2016\&actp=LIST

31. W. Więckowski, J. Adamus, "Friction and wear testing of titanium and aluminium alloys", Obróbka Plastyczna Metali, 23(3): 169-178, 2013.

32. Y-Q. Zheng, Z. Zhang, "The fire performance and fire-resistance design of aluminium alloy I-beam", Fire and Materials, 40: 141-157, 2016.

33. P. Zoetemeijer, "A design method for the tension side of statically loaded, bolted beam-to-column connections", Heron 20(1), Delft University, Netherlands, 1974.

\section{LIST OF FIGURES AND TABLES:}

Fig. 1. Mullion-transom wall system - aluminium profiles and brackets

Rys. 1. System fasadowy słupowo-ryglowy - profile aluminiowe oraz konsole

Fig. 2. Analyzed aluminium bracket

Rys. 2. Analizowana konsola aluminiowa

Fig. 3. Experimental material characteristic

Rys. 3. Charakterystyka materiałowa uzyskana z badań

Fig. 4. Analysed aluminium bracket with cover plates (straps)

Rys. 4. Analizowana konsola aluminiowa z podkładkami

Fig. 5. FEM solid model - a) model_1, b) model_2

Rys. 5. Model MES: a) model_1, b) model_2

Fig. 6. Displacement Uz - model_1

Rys. 6. Przemieszczenia Uz - model_1

Fig. 7. Total displacement-model_1

Rys. 7. Przemieszczenia globalne-model_1

Fig. 8. Equivalent von Mises stress - model_1

Rys. 8. Naprężenia zredukowane wg hipotezy HMH - model_1

Fig. 9. Displacement Uz - model_2

Rys. 9. Przemieszczenia Uz - model_2

Fig. 10. Total displacement - model_2

Rys. 10. Przemieszczenia globalne - model_2

Fig. 11. Equivalent von Mises stress - model_2 
Rys. 11. Naprężenia zredukowane wg hipotezy HMH - model_2

Fig. 12. Contact status - model_1: a) front view, b) rear view

Rys. 12. Kontakt - model_1: a) widok z przodu, b) widok z tyłu

Fig. 13. Contact status - model_2: a) front view, b) rear view

Rys. 13. Kontakt - model_2: a) widok z przodu, b) widok $z$ tyłu

Fig. 14. Uz and total displacements in base plate

Rys. 14. Przemieszczenia Uz oraz globalne przemieszczenia w blasze czołowej

Tab. 1. Material data for $6060 \mathrm{~T} 66$ at room temperature

Tab. 1. Dane materiałowe dla 6060 T66 w temperaturze pokojowej

Tab. 2. Mechanical properties of extruded profiles (EN AW-6060 T66) according to EN 755-2 [11]

Tab. 2. Właściwości mechaniczne profili ekstrudowanych (EN AW-6060 T66) według EN 755-2 [11]

Tab. 3. FEM analysis - material properties

Tab. 4. Results of FEM analysis
Tab. 3. Analiza MES - właściwości materiałów

Tab. 4. Wyniki analizy MES

Received 22.05.2017

Revised 04.06.2018

\section{ANALITYCZNA I NUMERYCZNA ANALIZA WZMOCNIONYCH KONSOL ALUMINIOWYCH}

Slowa kluczowe: konsole aluminiowe, właściwości mechaniczne, EN AW-6060 T66, wzmocnienie konsoli, MES

\section{STRESZCZENIE:}

W pracy przedstawiono numeryczne oraz analityczne badania nośności i sztywności wzmocnionych konsol aluminiowych. Są one stosowane jako elementy łącznikowe fasad słupowo-ryglowych z konstrukcją budynku. Konsole wykonano ze stopu aluminium AW-6060 wg PN-EN 573-3:2004, odmiana T66 wg PN-EN 515:1996. Wstępne analizy wytężania i zachowanie się konsol wykazały, że są one o niedostatecznej nośności oraz sztywności, czego podstawową przyczyną była zbyt wiotka ich blacha czołowa, a także jej otwory owalne montażowe. W celu zwiększania nośności i sztywności konsol zaproponowano zastosowanie nakładek (tzw. stempli), usytuowanych pod nakrętkami śrub łączących je z konstrukcją budynku. Wzmacniają one lokalnie blachy czołowe konsol. Ich zadaniem konstrukcyjnym jest m.in. zmniejszenie ramienia „zginania” c oraz zwiększenie sztywności giętnej blachy czołowej konsoli. W pracy dokonano krótkiego omówienia modeli materiałowych stosowanych do opisu stopu aluminium, wraz z podaniem wybranych parametrów materiałowych. Stworzono dwa bryłowe modele numeryczne konsol ze wzmocnieniem i bez wzmocnienia nakładkami, a następnie porównywano wartości ich przemieszczeń i naprężeń. W symulacjach numerycznych wykorzystano program MSC.Marc z opcją kontaktu (metoda kontaktu: segment-to-segment) pomiędzy elementami bryłowymi wraz z zdefiniowanym współczynnikiem tarcia bi-liniowego Colomba. Wykonane badania numeryczne wykazały, że wzmocnienie analizowanych konsol nakładkami (stemplami) zwiększyło ich nośność i sztywność o około $50 \%$, co pozwoliło w bezpieczny sposób przenieść prognozowane obciążenia na konstrukcję budynku. 